\title{
Does sovereign debt ratings news spill over to international stock markets?
}

\author{
Miguel A. Ferreira ${ }^{\mathrm{a}, *}$, Paulo M. Gama ${ }^{\mathrm{b}}$ \\ a ISCTE Business School-Lisbon, CEMAF, Complexo INDEG/ISCTE, \\ Av. Prof. Anibal Bettencourt, 1600-189 Lisboa, Portugal \\ ${ }^{\mathrm{b}}$ University of Coimbra, School of Economics, Av. Dias da Silva 165, 3004-512 Coimbra, Portugal
}

Received 29 September 2005; accepted 1 December 2006

Available online 25 January 2007

\begin{abstract}
The evidence here indicates that sovereign debt rating and credit outlook changes of one country have an asymmetric and economically significant effect on the stock market returns of other countries over 1989-2003. There is a negative reaction of 51 basis points (two-day return spread vis-á-vis the US) to a credit ratings downgrade of one notch in a common information spillover around the world. Upgrades, however, have no significant impact on return spreads of countries abroad. Closeness (e.g., geographic proximity) and emerging market status amplify the effect of a spillover. Downgrade spillover effects at the industry level are more pronounced in traded goods and small industries.
\end{abstract}

(C) 2007 Elsevier B.V. All rights reserved.

JEL classification: F30; G14; G15

Keywords: Sovereign ratings; Spillover effects; Stock market

\section{Introduction}

Does news about sovereign debt rating in one country impact stock markets in other countries? Our evidence indicates that negative sovereign rating news does spill over.

\footnotetext{
We thank an anonymous referee, Amar Gande, and seminar participants at the University of Porto for helpful comments.

${ }^{*}$ Corresponding author. Tel.: +351 21 7958607; fax: +351 217958605 .

E-mail address: miguel.ferreira@iscte.pt (M.A. Ferreira).
} 
We focus on the cross-country stock market reaction to Standard \& Poor's (S\&P) announcements of a sovereign credit rating or credit outlook change.

There is published research on this question. Brooks et al. (2004) study the own-country stock market impact of sovereign debt rating changes. They find that sovereign rating downgrades have a negative impact on the re-rated country's stock market (one-day abnormal returns of 197 basis points), but upgrades have an insignificant effect. Gande and Parsley (2005) find asymmetric international spillover effects on sovereign debt markets. Downgrades abroad are associated with a significant increase in sovereign bond spreads (12 basis points), but upgrades have an insignificant effect. Kaminsky and Schmukler (2002) show that emerging market sovereign rating news is contagious for bond and stock markets in emerging markets, particularly during periods of turmoil and particularly for neighboring countries.

The empirical question we address is whether sovereign rating news of one country is also relevant for other countries' stock markets. If market players see rating changes as a country-specific issue with no implications beyond country borders, little information impact would be expected. At the same time, either rational behavior due to liquidity constraints or irrational herding of investors and financial and real sector linkages across countries can act as transmission vehicles for country shocks (Dornbusch et al., 2000; Karolyi, 2003).

We extend the Gande and Parsley (2005) findings by investigating information spillover not only across countries but also across markets. That is, we focus on spillovers of credit rating or outlook of one country (the event country) to stock market return spreads (the return differential vis-á-vis the US) of all other countries (the non-event countries).

We consider a large set of countries, including not only emerging markets (18 countries) but also developed markets ( 11 countries), representing stocks totaling USD 4.9 trillion of market capitalization in 2002. We explicitly control for recent rating activity worldwide. We characterize the spillovers in economic terms, i.e., by including controls for capital flows and level of economic and financial development.

We also present several new results regarding cross-country and cross-market news spillover at the industry level. The evidence with regard to industry portfolios is of particular interest, given increasing investor perception that industry factors are becoming more important than country factors in explaining stock returns (see, for example, Cavaglia et al., 2000).

A sovereign credit rating represents a rating agency assessment of the capacity and the willingness of a sovereign obligator to meet its debt service payments in a timely fashion. They are understood by rating agencies as a forward-looking estimate of default probability; see Standard \& Poor's "Sovereign Credit Ratings (2005)". In most cases, the sovereign ceiling doctrine applies; that is, the rating assigned to non-sovereign debt issues (or issuers) is the same as or lower than the rating assigned to the sovereign of the country of domicile. Thus, sovereign rating revisions also relate to non-sovereign debt instruments (Radelet and Sachs, 1998; BIS, "International Convergence", 2004). ${ }^{1}$

\footnotetext{
${ }^{1}$ The Basel II Accord provides examples of the sovereign rating ceiling doctrine. Under the standardized approach to minimum capital requirements for bank claims (option 1), all banks incorporated in a given country are assigned a risk weight one category less favorable than the risk assigned to claims on the sovereign of that country. For claims on corporations, no claim on an unrated corporation can be given a risk weight more favorable than that assigned to its sovereign country of incorporation.
} 
The stock market should be expected to react to a sovereign rating downgrade because a downgrade can affect a country's ability to borrow in international markets, and thus contribute to a credit crunch, which negatively impacts the stock market. Other mechanisms as well reveal a link between sovereign rating and stock markets. Sovereign rating can provide information on the future economic health of the rated country that is not otherwise available to stock market participants, and governments can take policy actions that directly affect companies' future prospects (e.g., raising corporate taxes to compensate for increased debt service following a downgrade). Moreover, because many institutional investors can hold only investment-grade instruments, rating downgrades and (upgrades) may have a negative (positive) impact on security prices.

Our work is related to the literature on stock and bond market correlation. Campbell and Ammer (1993) show that stocks and bonds react in the same direction to news about fundamentals, with the exception of news about inflation. Other evidence on low (or even negative) stock-bond correlation is inconclusive as to the expected direction of the reaction to a rating revision (Connolly et al., 2005). At the corporate bond level, there is theoretical support for both a positive and a negative reaction to corporate bond rating downgrades; see, for instance, Zaima and McCarthy (1988).

Our major findings can be summarized as follows. First, we find rating changes in one country incorporate valuable information for the aggregate stock market returns of other countries. The spillover effect is asymmetric, both in direction of the reaction and in terms of economic impact. A one-notch rating downgrade abroad is associated with a statistically significant negative return spread of 51 basis points on average across non-event countries. No significant impact is found for rating upgrades.

Second, controlling for time-invariant characteristics that proxy for underlying similarities between countries affects the asymmetric nature of spillovers. We control for the cultural, regional, and institutional environment as well as level of economic and financial development. We find that geographic distance is inversely related to the spillover impact. This is consistent with the hypothesis that rating news has a more pronounced effect in countries nearby where the information asymmetry is moderated. We also find that the downgrade impact is more pronounced in emerging stock markets. This is consistent with the hypothesis of a more pronounced common information spillover across emerging markets.

Finally, we show that rating downgrades also have a significant effect on local industry portfolio return spreads. Sovereign rating downgrades abroad are associated with a highly statistically significant negative two-day return spread of industry portfolios vis-á-vis their counterpart industry in the US. The negative effect of downgrades is pervasive across industries, but it is more pronounced in traded-goods and small industries.

\section{Research design}

We discuss our data, rating events, and test procedures separately.

\subsection{Data}

We examine the cross-country spillover effects of sovereign rating revisions using the S\&P history of sovereign rating for the countries analyzed by Gande and Parsley (2005) that are included in the TF Datastream Global Equity Indices database. The data cover 
the period from July 3, 1989, through December 31, 2003. The starting date represents the first complete month S\&P debt rating and credit outlook information are available.

We prefer the S\&P foreign currency long-term rating history over other agencies' rating history because of data availability. Moreover, S\&P tends to be more active in making rating revisions, and tends to lead other agencies in re-rating (Kaminsky and Schmukler, 2002; Brooks et al., 2004; Gande and Parsley, 2005). Foreign currency rating announcements by S\&P also seem to convey a greater own-country stock market impact and seem not to be fully anticipated by the market (Reisen and von Maltzan, 1999; Brooks et al., 2004). ${ }^{2}$

A preliminary analysis of our data shows that the re-rated country two-day $[0,1]$ return spread relative to the US is, on average, 146 basis points on S\&P rating downgrades announcement days. This result is consistent with the own-market wealth effects of downgrades documented by Brooks et al. (2004).

The countries in our dataset must meet two criteria. They have publicly traded US dollar-denominated sovereign debt, and country-level portfolio total return index data are available in the TF Datastream database. The 29 countries meeting these criteria are: Argentina, Austria, Belgium, Brazil, Canada, Chile, China, Colombia, Denmark, Finland, Greece, Hungary, Indonesia, Ireland, Israel, Italy, Korea, Malaysia, Mexico, New Zealand, Philippines, Poland, South Africa, Spain, Sweden, Thailand, Turkey, the UK, and Venezuela. Thus, we build a geographically balanced sample that includes both emerging and developed countries. The stock market indexes considered here represent about $80 \%$ of each country's stock market capitalization and are constructed using similar methods across countries.

We also use data on several country-specific control variables (Table A.1 in the Appendix details the variable definitions and data sources). Classification of countries as emerging or developed is based on Morgan Stanley Capital International, S\&P, and ISI Emerging Markets. A country is classified as emerging if it is listed as emerging by at least one of these sources. ${ }^{3}$

We consider bilateral dummy variables for sharing a common language, adjacency (or common land border), legal tradition, and membership in a formal trade bloc, either the North American Free Trade Agreement (NAFTA), the Mercado Comun del Sur (Mercosur), the European Union (EU), or the Association of South East Asian Nations (ASEAN). We also explicitly control for physical distance between countries, computed as the great circle distance between capital cities. These variables are intended to control for historical factors that may influence spillover effects because they proxy for similarities between countries that could heighten common spillover effects; see Gande and Parsley (2005). Geographic factors akin to our control variables are standard controls in the literature explaining cross-country economic flows and also relate to linkages across stock markets (Rose, 2000; Portes and Rey, 2005).

We explicitly control for crisis periods by including dummy variables for the European Exchange Rate Mechanism crisis of 1992-1993, the Tequila crisis of 1994, the Asian Flu of 1997, and the recent crises in Russia, Brazil, Turkey, and Argentina. These crisis periods

\footnotetext{
${ }^{2}$ Sovereign rating history comes from the S\&P website: http//www.standardandpoors.com.

${ }^{3}$ Greece is the only country in the sample that was upgraded from emerging to developed either by S\&P or MSCI; we classify it as an emerging market. Countries classified as developed are Austria, Belgium, Canada, Denmark, Finland, Ireland, Italy, New Zealand, Spain, Sweden, and the UK.
} 
include a total of 49 rating events. Finally, we use the Bekaert and Harvey (2000) and Bekaert et al. (2003) "official liberalization" dates to control for emerging market segmentation from the world market due to regulatory constraints on international capital flows.

\subsection{Ratings events}

We define a rating event as a change in either the explicit credit rating or the credit outlook assigned to a specific sovereign foreign currency debt. This is consistent with recent work on the spillover effects of sovereign rating revisions that accounts for effective rating announcements as well as information on imminent rating actions in a comprehensive credit rating (CCR) measure. The changes to $\mathrm{CCR}$ define our rating events.

Table A.2 in the Appendix presents the details on the numerical coding of the CCR measure. First, we map letter explicit rating to numerical codes by a linear transformation to a scale from 0 (the lowest rating, SD/D) to 20 (the highest rating, AAA). Next, we add the credit outlook information (on a scale between -1 for a negative credit outlook and +1 for a positive credit outlook) to the rating numerical code. Any non-zero change in the comprehensive credit rating measure defines the events of interest: "upgrade", a positive change resulting from an upward move in the (letter) credit rating of the sovereign or from a favorable revision in the credit outlook; and, "downgrade", a negative change resulting from a downward move in the (letter) rating or from an unfavorable revision in the credit outlook.

Table 1 describes the sovereign rating events sample. There are 106 upgrades and 109 downgrades between July 1989 and December 2003. The vast majority of events are announced individually (for one country on a given day), although multiple-event days occur for $14.1 \%$ of the upgrades, and $3.7 \%$ of the downgrades (see Panel A). The time clustering of events can also be evaluated by looking at the average time elapsed between events and the time periods in which they occur. Panel B of Table 1 shows that just over $50 \%$ of the events (54 upgrades and 59 downgrades) occur within a window of two weeks (ten trading days). Panel $\mathrm{C}$ shows that just over $45 \%$ of the events (54 upgrades and 44 downgrades) are announcements made after 1998.

The strong temporal association of events suggests the use of a short event-window in evaluating the impact of rating revisions and to explicitly control for worldwide recent rating activity. The use of a long event-window can bias results because stock returns in the (longer) event window can incorporate rating changes in countries beyond the country being evaluated. Moreover, if markets see rating revisions in the context of recent rating activity, today's reaction will be a function of prior rating revisions.

In fact, Kaminsky and Reinhart (2000) show that domestic markets become sharply more susceptible to crises elsewhere if a core group of countries (not one single country) are already affected. If the same type of behavior characterizes home-country reaction to sovereign rating changes abroad, this implies that events in other countries can cumulate.

Panel D of Table 1 divides the rating events by emerging or developed country. Not surprisingly, the vast majority of events, about $85 \%$, occur in emerging markets. Investigating whether rating news also affects developed stock markets has been overlooked in the literature.

Finally, Panel E of Table 1 divides rating events according to the change in the CCR measure. The vast majority of events are one-notch changes, although half-notch events 
Table 1

Description of sovereign ratings events

\begin{tabular}{|c|c|c|c|c|c|c|}
\hline & \multicolumn{2}{|l|}{ Upgrades } & \multicolumn{2}{|c|}{ Downgrades } & \multicolumn{2}{|l|}{ All } \\
\hline & Frequency & Percent & Frequency & Percent & Frequency & Percen \\
\hline \multicolumn{7}{|c|}{ Panel A: Number of events on a single day } \\
\hline 1 & 91 & 85.9 & 105 & 96.3 & 196 & 61.2 \\
\hline 2 & 8 & 7.5 & 4 & 3.7 & 12 & 5.6 \\
\hline 3 & 3 & 2.8 & 0 & 0.0 & 3 & 1.4 \\
\hline 4 & 4 & 3.8 & 0 & 0.0 & 4 & 1.9 \\
\hline
\end{tabular}

Panel B: Number of events within a window

$\begin{array}{lllllrl}\text { 1-Week } & 37 & 34.9 & 35 & 32.1 & 72 & 33.5 \\ \text { 2-Week } & 54 & 50.9 & 59 & 54.1 & 113 & 52.6 \\ \text { 3-Week } & 69 & 65.1 & 74 & 67.9 & 143 & 66.5 \\ \text { 4-Week } & 75 & 70.8 & 81 & 74.3 & 156 & 72.6\end{array}$

Panel C: Number of events by subperiod

$\begin{array}{rrrrrrr}1989-1998 & 52 & 49.1 & 65 & 59.6 & 117 & 54.4 \\ 1999-2003 & 54 & 50.9 & 44 & 40.4 & 98 & 45.6\end{array}$

Panel D: Number of events by development status

$\begin{array}{lrrrrrr}\text { Emerging } & 88 & 83.0 & 95 & 87.2 & 183 & 85.1 \\ \text { Developed } & 18 & 17.0 & 14 & 12.8 & 32 & 14.9\end{array}$

Panel E: Number of events by CCR change

\begin{tabular}{lrrrrrr}
$<$ One notch & 5 & 4.7 & 16 & 14.7 & 21 & 9.8 \\
One notch & 91 & 85.9 & 73 & 67.0 & 164 & 76.3 \\
$>$ One notch & 10 & 9.4 & 20 & 18.3 & 30 & 14.0 \\
\hline
\end{tabular}

This table shows the number of comprehensive credit ratings (CCR) changes that occur on a single day (Panel A), in a given week window (Panel B), from 1989 to 1998 and from 1990 to 2003 (Panel C), in countries whose stock market is classified as emerging or developed (Panel D), and according to the CCR change (Panel E).

and more than one-notch events represent $23.7 \%$ of all events $(14.1 \%$ for upgrades and $33.0 \%$ for downgrades).

\subsection{Test procedures}

We extend the methodology that Gande and Parsley (2005) use to study the impact of rating changes in international stock markets. We measure the non-event country $j(\neq i)$ stock market response to a rating event in country $i(\neq j)$ by the daily logarithmic change in the country $j$ total return index relative to the equivalent change in the US market total return index (the benchmark). To account for time zone differences between stock markets, we cumulate the "stock market spreads" in a standard two-day window $[0,1]$.

To measure the reaction to a rating downgrade or upgrade, we add a country-matched random sample (with replacement from the original time series excluding the observations within a two-month window centered in each event day) of 215 non-event days (the total number of rating events) to our sample of event days. The overall sample (215 event days plus the sample of 215 non-event days) cumulative two-day [0,1] return spread is 
characterized by a mean (median) return spread of $-0.014 \%(-0.002 \%)$ and a standard deviation of $2.820 \%{ }^{4}$

We pool the data for all countries $(j)$ excluding the event country $(i)$, at each event or randomly selected non-event time $(t)$, and estimate a benchmark regression separately for upgrades and downgrades

$$
r_{j, t}=\alpha+\beta_{1} \text { Event }_{i, t}+\sum_{k} \beta_{k} X_{k}+\epsilon_{i j, t} \quad \forall j \notin i,
$$

where $r_{j, t}$ represents the cumulative $[0,1]$ return spread. Event ${ }_{i, t}$ takes a value equal to the change in the CCR measure on event days and zero on non-event days. For ease of interpretation, we use the absolute value of Event ${ }_{i, t}$ in the downgrade regression. Since we analyze upgrades and downgrades separately, this allows for an interpretation of the stock market reaction as "in the expected direction, given the announcement". Matrix $X$ includes full sets of year and country dummies ( 29 event country and 29 non-event country) and the levels of event and non-event country comprehensive credit rating. The latter controls for non-linearities in market reaction relative to the position of each country pair on the rating scale. ${ }^{5}$

Our approach has two major advantages. First, it allows for great flexibility in testing alternative hypotheses. For instance, to control for time-invariant country-specific characteristics in subsequent regressions, the matrix $X$ is expanded to include additional controls, including emerging/developed status, common language, adjacency, physical distance, legal tradition, and membership in a formal trade bloc. Likewise, we can test for the impact of crisis periods or stock market liberalizations by adding specific variables to the matrix $X$.

Second, we control for the temporal clustering of events by measuring the change in stock prices over a short window of two days, rather than relying on a longer window (e.g., 30 days), and by explicitly controlling for the intensity of past events with the inclusion of a new variable, Lag Event, which measures the net rating change (event country prior CCR changes excluded) in the preceding two (or three) weeks. Thus, we control for non-linearities in relation to the recent worldwide history of rating activity.

Our methodology differs from that in Gande and Parsley (2005), as they use a sample that considers only event days (the Event ${ }_{i, t}$ variable includes only non-zero values). In this case, the Event ${ }_{i, t}$ coefficient measures the incremental reaction to a rating change of more than one notch. To complement our basic results and make them comparable with the Gande and Parsley (2005) results, we also present results using a sample of only event days.

\section{Empirical results}

We discuss the results in several different respects. First, we measure the stock market spillover effect of rating news relative to a random sample of non-event days. Second, we discuss several robustness tests of our primary findings. We then present evidence of the

\footnotetext{
${ }^{4}$ Simple "market-adjusted" abnormal stock returns are used in, for example, Griffin and Stulz (2001) and Kaminsky and Schmukler (2002). In the literature that focuses on bond market reactions to sovereign ratings revisions, the standard approach relies on bond yield spreads relative to comparable-maturity US bond yields, mainly because it is hard to find a relevant event-free period (see, for example, Reisen and von Maltzan, 1999).

${ }^{5}$ We do run regressions including the lag return spread as an explanatory variable to account for possible leadlag relations in national market index returns. The conclusions remain virtually unchanged, so these new results are not tabulated here but are available upon request.
} 
incremental stock market reaction to rating events abroad using a sample of only event days. Finally we examine the effect of rating events in terms of international stock market correlations and spillover effects at the industry portfolio level.

\subsection{International stock market impact of sovereign rating news}

Table 2 reports estimates of the coefficients in Eq. (1). There is evidence that sovereign debt rating changes abroad produce an asymmetric common information spillover effect on stock markets. Sovereign debt rating upgrades are associated with a positive effect on stock market prices relative to the US, and downgrades with a negative effect. In other words, on the days a sovereign credit rating for a particular country is upgraded (or a credit outlook improved), our results suggest that the remaining countries do better than the US market. When a country is downgraded, the results show that the remaining countries do much worse than the US market.

Only for downgrades is the effect statistically significant at the $5 \%$ level. The downgrade effect is also economically more meaningful than the upgrade effect. A one-notch negative event in one country is associated with an average negative two-day stock market return spread abroad of about 51 basis points, while positive events are associated with positive return spreads of less than four basis points (see specifications 1a and 1b).

Negative news in the sovereign debt market, but not positive news, does seem to have a significant impact on the stock markets of non-event countries. One possible explanation for the asymmetric common information effect of rating news is that upgrades are in part anticipated by market participants, unlike downgrades. This anticipation could occur through information leakages (or pre-event information disclosure) of the imminent upgrade by the event country government. In the case of a downgrade, rating agencies probably try harder to avoid an information leakage. Another possible explanation is that rating agencies are more reluctant to downgrade a sovereign rating than to upgrade for marketing reasons (Larrain et al., 1997). Finally, market participants can recognize downgrades (but not upgrades) as a wake-up call, especially during bad times.

Interestingly, the level of event country comprehensive credit raing is significant only for upgrades. The higher the event country CCR, the lower the non-event country stock market response for rating upgrades, suggesting that the effect of upgrades is most marked for low-quality sovereign rating. Moreover, the coefficient of the Lag Event variable (the control for clustering in events in other countries by measuring rating activity in the prior two weeks) is insignificant, which suggests that rating history does not matter. This reinforces the intuition that the stock market understands downgrades as surprises. The insignificance of the lagged event variable coefficient for downgrades also does not offer support for a delayed stock market reaction to a rating change abroad.

Overall, these results support an asymmetric common information effect of a downgrade in international stock markets. Across asset markets and across countries, bad news in one country is interpreted as negative news in other countries. Positive news has no discernible impact. ${ }^{6}$

\footnotetext{
${ }^{6}$ The probit model estimates and Granger causality tests in Gande and Parsley (2005), whose sample of countries is similar to ours, allow the rejection of spillover effects on the comprehensive credit ratings themselves. In other words, these results allow us to eliminate the possibility that spillover effects are anticipated by rating agencies and that ratings are adjusted simultaneously across countries.
} 
International stock market impact of sovereign rating news

\begin{tabular}{|c|c|c|c|c|c|c|c|c|c|c|c|c|}
\hline & \multicolumn{6}{|c|}{ Upgrades } & \multicolumn{6}{|c|}{ Downgrades } \\
\hline & \multicolumn{2}{|l|}{ (1a) } & \multicolumn{2}{|l|}{$(2 \mathrm{a})$} & \multicolumn{2}{|l|}{ (3a) } & \multicolumn{2}{|l|}{ (1b) } & \multicolumn{2}{|l|}{$(2 b)$} & \multicolumn{2}{|l|}{$(3 b)$} \\
\hline & Coeff & $t$-stat & Coeff & $t$-stat & Coeff & $t$-stat & Coeff & $t$-stat & Coeff & $t$-stat & Coeff & $t$-stat \\
\hline Constant & 1.3237 & 3.552 & 0.4248 & 0.739 & 1.3787 & 3.689 & 0.8023 & 2.103 & 0.7499 & 1.184 & 0.8220 & 2.159 \\
\hline Event & 0.0364 & 0.587 & 0.0378 & 0.605 & 0.2242 & 1.813 & -0.5141 & -5.734 & -0.5095 & -5.684 & -0.7526 & -4.442 \\
\hline Lag Event & 0.0002 & 0.004 & 0.0066 & 0.140 & -0.0072 & -0.149 & 0.0601 & 1.269 & 0.0597 & 1.264 & 0.0606 & 1.258 \\
\hline CCR (event country) & -0.1303 & -6.294 & -0.1280 & -6.179 & -0.1309 & -6.313 & -0.0253 & -1.267 & -0.0241 & -1.211 & -0.0242 & -1.210 \\
\hline CCR (non-event country) & 0.0233 & 0.921 & 0.0288 & 1.141 & 0.0274 & 1.085 & -0.0298 & -1.009 & -0.0274 & -0.930 & -0.0337 & -1.129 \\
\hline Emerging & & & 0.9929 & 2.094 & & & & & -0.2520 & -0.487 & & \\
\hline Developed & & & -0.4740 & -0.972 & & & & & 0.6783 & 1.252 & & \\
\hline Adjacent & & & -0.0547 & -0.301 & & & & & 0.2175 & 1.119 & & \\
\hline Distance & & & -0.0101 & -1.065 & & & & & 0.0207 & 1.908 & & \\
\hline Language & & & 0.0573 & 0.546 & & & & & 0.1075 & 0.943 & & \\
\hline Trade bloc & & & 0.2126 & 1.404 & & & & & 0.0407 & 0.223 & & \\
\hline Common law & & & -0.0854 & -0.591 & & & & & 0.0073 & 0.043 & & \\
\hline Emerging $\times$ Event & & & & & -0.0834 & -0.884 & & & & & -0.2453 & -1.938 \\
\hline Developed $\times$ Event & & & & & 0.3597 & 1.839 & & & & & 0.2361 & 0.797 \\
\hline Adjacent $\times$ Event & & & & & 0.1683 & 0.450 & & & & & 0.4613 & 1.100 \\
\hline Distance $\times$ Event & & & & & -0.0145 & -1.465 & & & & & 0.0336 & 2.304 \\
\hline Language $\times$ Event & & & & & -0.1937 & -1.442 & & & & & 0.1960 & 1.281 \\
\hline Trade bloc $\times$ Event & & & & & 0.1269 & 0.656 & & & & & -0.0948 & -0.258 \\
\hline Common law $\times$ Event & & & & & -0.0928 & -0.588 & & & & & 0.2655 & 1.045 \\
\hline Year dummies & \multicolumn{2}{|c|}{ Yes } & \multicolumn{2}{|c|}{ Yes } & \multicolumn{2}{|c|}{ Yes } & \multicolumn{2}{|c|}{ Yes } & \multicolumn{2}{|c|}{ Yes } & \multicolumn{2}{|c|}{ Yes } \\
\hline Event country dummies & \multicolumn{2}{|c|}{ Yes } & \multicolumn{2}{|c|}{ Yes } & \multicolumn{2}{|c|}{ Yes } & \multicolumn{2}{|c|}{ Yes } & \multicolumn{2}{|c|}{ Yes } & \multicolumn{2}{|c|}{ Yes } \\
\hline Non-event country dummies & \multicolumn{2}{|c|}{ Yes } & \multicolumn{2}{|c|}{ Yes } & \multicolumn{2}{|c|}{ Yes } & \multicolumn{2}{|c|}{ Yes } & \multicolumn{2}{|c|}{ Yes } & \multicolumn{2}{|c|}{ Yes } \\
\hline Adjusted $R^{2}$ & \multicolumn{2}{|c|}{0.028} & \multicolumn{2}{|c|}{0.030} & \multicolumn{2}{|c|}{0.029} & 0.0 & & 0. & & 0.0 & \\
\hline Number of observations & & & 77 & & & & 77 & & 77 & & 77 & \\
\hline
\end{tabular}

This table presents the coefficient estimates of Eq. (1) using a sample of event days and randomly selected (with replacement) non-event days. Event is the change in the comprehensive credit rating (CCR) on event days and zero on non-event days. Lag Event is the cumulative change in the CCR of non-event countries during the two weeks preceding the event. Matrix $X$ includes the levels of event and non-event country CCR, country status as emerging/developed, adjacency (sharing of land border), distance between countries, sharing a common official language, membership in a trade bloc, origin of legal systems, and full sets of year and country (event and non-event) dummies. The dependent variable is the cumulative two-day [0,1] non-event country stock market return spread relative to the US stock market, denominated in US dollars. All $t$-statistics ( $t$-stat) are heteroskedasticity-robust using the White correction. 
The second specification in Table 2 [specifications (2a) and (2b)] further investigates the effect of rating events relative to non-event days controlling for time-invariant characteristic that proxy for underlying similarities between countries. We control for the cultural, regional, and institutional environment as well as the level of economic and financial development. Adding these control variables leaves our primary findings unchanged.

The third specification in Table 2 [specifications (3a) and (3b)] tests whether spillover effects are more pronounced according to country characteristics. We hypothesize that the spillover effect is more pronounced in emerging markets and in countries operating under civil law. In fact, the stock market reaction, especially to negative news, may be enhanced in countries with weak legal institutions. We also hypothesize that the spillover effect is more pronounced in countries that share a common border or a common language, in countries that are closer (i.e., countries near one another), and in countries in the same trade bloc. The argument is that proximity or familiarity between countries may enhance the stock market reaction to rating news. To test these hypotheses, we interact the Event variable with these country characteristics.

We interpret the opposite sign of the physical distance interaction variable relative to the event variable as evidence that added distance between countries diminishes the average wealth impact of spillovers. Therefore, there is a greater stock market effect of rating news abroad when countries are closer, which is consistent with the information asymmetry hypothesis. This finding is contrary to the sovereign debt market evidence in Gande and Parsley (2005), who find that familiarity variables do not affect the estimated spillover. These different results should come as no surprise, as there is much greater information asymmetry in stock markets than in sovereign debt markets. ${ }^{7}$

The coefficient of the interaction of the emerging market dummy variable (which takes a value of one when both event and non-event countries are classified as emerging) with the Event variable is significant in the downgrade regression, suggesting a more pronounced impact among emerging country stock markets (excluding the event country) of a negative event in an emerging market country. The additional interaction variables are in general statistically insignificant at the 5\% level.

\subsection{Robustness tests}

Table 3 presents results of several robustness tests of the basic specification used to evaluate the international stock market impact of sovereign rating revisions.

\subsubsection{Currency effects}

We first examine the definition of stock market return spreads by explicitly removing currency effects from the calculation. That is, we use local currency-denominated returns to compute the differential return vis-á-vis the US market.

The negative impact of downgrades on international stock markets increases in statistical significance, but the economic impact remains virtually the same. Downgrades are associated with a response of stock markets abroad of 51 basis points (negative two-day

\footnotetext{
${ }^{7}$ Results (not tabulated here) including both the country characteristics and the interaction variables provide similar findings.
} 
Table 3

International stock market impact of sovereign rating news: Robustness tests

\begin{tabular}{|c|c|c|c|c|c|c|c|c|c|c|c|c|c|c|c|c|}
\hline & \multicolumn{8}{|l|}{ Upgrades } & \multicolumn{8}{|c|}{ Downgrades } \\
\hline & \multicolumn{2}{|c|}{ Local currency } & \multicolumn{2}{|c|}{ Market model } & \multicolumn{2}{|l|}{ Crisis } & \multicolumn{2}{|c|}{ Liberalization } & \multicolumn{2}{|c|}{ Local currency } & \multicolumn{2}{|c|}{ Market model } & \multicolumn{2}{|l|}{ Crisis } & \multicolumn{2}{|c|}{ Liberalization } \\
\hline & Coeff & $t$-stat & Coeff & $t$-stat & Coeff & $t$-stat & Coeff & $t$-stat & Coeff & $t$-stat & Coeff & $t$-stat & Coeff & $t$-stat & Coeff & $t$-stat \\
\hline Constant & 1.4517 & 4.312 & 0.6039 & 1.302 & 1.2926 & 3.473 & 1.3477 & 3.599 & 1.0643 & 3.058 & 0.5926 & 1.283 & 0.6909 & 1.786 & 0.8189 & 2.132 \\
\hline Event & 0.0060 & 0.111 & 0.0743 & 0.984 & 0.0295 & 0.465 & 0.0385 & 0.614 & -0.5151 & -6.467 & -0.3750 & -3.939 & -0.5381 & -4.904 & -0.5096 & -5.630 \\
\hline Lag Event & 0.0276 & 0.696 & -0.0295 & -0.565 & -0.0091 & -0.190 & 0.0004 & 0.008 & 0.0846 & 2.091 & 0.0735 & 1.572 & 0.0434 & 0.895 & 0.0602 & 1.269 \\
\hline $\begin{array}{c}\text { CCR (event } \\
\text { country) }\end{array}$ & -0.1153 & -6.008 & -0.0913 & -3.278 & -0.1275 & -6.169 & -0.1300 & -6.275 & -0.0417 & -2.281 & 0.0092 & 0.368 & -0.0144 & -0.719 & -0.0246 & -1.231 \\
\hline $\begin{array}{l}\text { CCR (non-event } \\
\text { country) }\end{array}$ & 0.0169 & 0.735 & -0.0082 & -0.282 & 0.0227 & 0.897 & 0.0220 & 0.867 & -0.0189 & -0.729 & -0.0845 & -2.150 & -0.0279 & -0.945 & -0.0312 & -1.051 \\
\hline Crisis & & & & & -0.4956 & -2.100 & & & & & & & -0.6885 & -2.984 & & \\
\hline Crisis $\times$ Event & & & & & -0.1715 & -0.627 & & & & & & & 0.3012 & 1.533 & & \\
\hline Liberal (no) & & & & & & & -0.1295 & -0.815 & & & & & & & -0.0892 & -0.518 \\
\hline $\begin{array}{c}\text { Liberal (no) } \\
\times \text { Event }\end{array}$ & & & & & & & -0.0846 & -0.245 & & & & & & & -0.2045 & -0.640 \\
\hline Year dummies & \multicolumn{2}{|c|}{ Yes } & \multicolumn{2}{|c|}{ Yes } & \multicolumn{2}{|c|}{ Yes } & \multicolumn{2}{|c|}{ Yes } & \multicolumn{2}{|c|}{ Yes } & \multicolumn{2}{|c|}{ Yes } & \multicolumn{2}{|c|}{ Yes } & \multicolumn{2}{|c|}{ Yes } \\
\hline $\begin{array}{l}\text { Event country } \\
\text { dum. }\end{array}$ & \multicolumn{2}{|c|}{ Yes } & \multicolumn{2}{|c|}{ Yes } & \multicolumn{2}{|c|}{ Yes } & \multicolumn{2}{|c|}{ Yes } & \multicolumn{2}{|c|}{ Yes } & \multicolumn{2}{|c|}{ Yes } & \multicolumn{2}{|c|}{ Yes } & \multicolumn{2}{|c|}{ Yes } \\
\hline $\begin{array}{l}\text { Non-event } \\
\text { country dum. }\end{array}$ & \multicolumn{2}{|c|}{ Yes } & \multicolumn{2}{|c|}{ Yes } & \multicolumn{2}{|c|}{ Yes } & \multicolumn{2}{|c|}{ Yes } & \multicolumn{2}{|c|}{ Yes } & \multicolumn{2}{|c|}{ Yes } & $\mathrm{Ye}$ & & $\mathrm{Y}$ & \\
\hline Adjusted $R^{2}$ & 0.0 & & 0.0 & & 0.03 & & 0.0 & & 0.0 & & 0.0 & & 0.0 & & 0. & \\
\hline $\begin{array}{l}\text { Number of } \\
\text { observations }\end{array}$ & 77 & & 47 & & 774 & & 77 & & 77 & & 50 & & 770 & & 77 & \\
\hline
\end{tabular}

This table presents the coefficient estimates of Eq. (1) using a sample of event days and randomly selected (with replacement) non-event days. Event is the change in the comprehensive credit rating (CCR) on event days and zero on non-event days. Lag Event is the cumulative change in the CCR of non-event countries during the two weeks preceding the event. Matrix $X$ includes the levels of event and non-event country CCR. In the first specification, the dependent variable is the cumulative two-day $[0,1]$ non-event country stock market return spread relative to the US stock market, denominated in local currency. In the second specification, the dependent variable is the cumulative two-day [0,1] abnormal return from a market model (benchmark is the US stock market) estimated monthly over a centered window of 36 months (excluding the event months $-1,0,+1$ ). In the final two specifications, the dependent variable is the cumulative two-day $[0,1]$ non-event country stock market return spread relative to the US stock market, denominated in US dollars. In the final two specifications, the matrix $X$ includes alternatively controls for crisis and no liberalization (Liberal) periods. All $t$-statistics ( $t$-stat) are heteroskedasticity-robust using the White correction. 
stock return spreads in local currency). Upgrades abroad do not trigger a significant response at home.

\subsubsection{Market model abnormal returns}

We use market model-adjusted spreads (taking the US stock market as a benchmark) instead of simple return spreads. We follow Goh and Ederington (1993) and use a rolling window of 36 months (excluding the event months $-1,0$, and +1 ) centered on each event month (or the month of randomly selected observations), to compute the market model parameters using monthly returns. Then we use the estimated parameters to compute daily abnormal returns cumulated over the two-day $[0,1]$ event window.

Our basic findings of an asymmetric international impact continue to hold. The negative impact of downgrades is slightly lower at 37.5 basis points. There is no significant response for upgrades. ${ }^{8}$

\subsubsection{Crisis periods}

We ask whether the rating events that occurred during periods of capital market turmoil (49 events) could be driving our results. Crisis periods include the European Exchange Rate Mechanism crisis of 1992-1993, the Tequila crisis of 1994, the Asian Flu of 1997, and the recent crises in Russia, Brazil, Turkey, and Argentina. The basic results remain unchanged when we control for these crisis periods. That is, only negative rating news is associated with a significant international stock market reaction.

Interestingly, the crisis dummy is statistically significant and negative in both upgrade and downgrade regressions. This result suggests that the information content of rating upgrades during periods of turmoil is outweighed by the negative expectations stock market players are acting upon, while a downgrade abroad during a period of international financial crisis contributes to an increased negative impact at home.

\subsubsection{Liberalization}

If foreign investor actions are relevant in transmitting information across markets, we would expect smaller spillover effects for countries whose practice is to erect barriers to the trading of local equities by foreign investors. To account for this effect, we expand the basic specification to include a non-event country dummy variable that equals one if a rating change occurs before the country's official liberalization, and zero otherwise.

There continue to be spillovers only for downgrades, and the liberalization effect is not statistically significant.

\subsubsection{Large countries}

We also check the results by looking at a subsample of different size countries. We use gross domestic product (GDP) to proxy for country size. Because larger countries are more important in the international debt market and receive more attention from global investors, we expect information spillovers from them to be economically more significant. We focus on the 15 countries with purchasing power-adjusted GDP of more than 300 billion USD in 2002.

\footnotetext{
${ }^{8}$ Results not tabulated here, but available upon request, show that the conclusions also continue to hold when we expand the window to three weeks to measure the cumulative impact of consecutive ratings changes.
} 
We find that downgrades of large countries have a more pronounced impact than downgrades of small countries. A large-country downgrade is associated with a significant incremental negative return spread of 72 basis points across all other countries and of 88 basis points across all other large countries. ${ }^{9}$

\subsection{Incremental spillover effect}

Table 4 reports estimates of the coefficients in Eq. (1) using a sample of only event days following the Gande and Parsley (2005) methodology. In this case, the Event coefficient measures the incremental reaction to a rating change of more than one notch. The results suggest an asymmetric incremental information spillover effect on stock markets of sovereign debt rating changes abroad. An incremental one-notch negative event in one country is associated with an average negative two-day stock market return spread abroad of about 28 basis points, while positive events are associated with positive return spreads of about half that size.

Among the economic characterization variables, physical distance is statistically significant both in upgrade and downgrade regressions. To the extent that there is less information asymmetry in countries near each other, common information spillovers are accentuated by geographic proximity. The development status coefficient (i.e., when event and non-event country are both developed) is also significant in the downgrade regression. This is evidence that common information spillovers are less important among developed countries. The additional control variables (e.g., adjacency) are statistically insignificant at the $5 \%$ level.

We further characterize the incremental spillovers patterns by explicitly accounting for foreign equity portfolio (and trade) flows linkages. Following the reasoning of Gande and Parsley (2005), we hypothesize that common information spillover effects should dominate for two countries with highly positively correlated portfolio (or trade) flows. Differential spillover effects (or "contrary to expected" reactions) are more likely between countries with highly negatively correlated portfolio (or trade) flows. ${ }^{10}$

We investigate this hypothesis by considering the time series correlation of gross portfolio or trade flows vis-á-vis the US for each country in our sample. At each event date, we use a moving window of the most recent six-month portfolio or trade flows to compute the correlation between the event country flows and all the remaining (non-event) countries. Next, we construct a dummy variable that takes a value of one for country pairs with high positive correlation (the top quartile of the cross-sectional distribution), and zero otherwise. Similarly, a dummy variable is also constructed for the country pairs that fall in the bottom quartile (highly negative correlation). Results including the flows correlation variables are reported in the final two specifications of Table 4 [specification (3a) and (3b) for portfolio flows and specification (4a) and (4b) for trade flows].

Two findings stand out. First, controlling for portfolio or trade flows correlation does not change our basic findings that only for downgrades is there a significant incremental common information spillover effect. Furthermore, the statistical insignificance of the

\footnotetext{
${ }^{9}$ More detailed results are available from the authors upon request.

${ }^{10}$ Data on monthly bilateral capital and trade flows between each country and the US are obtained from the US Treasury's Treasury International Capital (TIC) reporting system (gross flows-sales plus purchases-of foreign stocks) and from the US Census Department (monthly bilateral-with the US-trade flows).
} 
Table 4

International stock market impact of sovereign rating news: Incremental reaction

\begin{tabular}{|c|c|c|c|c|c|c|c|c|c|c|c|c|c|c|c|c|}
\hline & \multicolumn{8}{|l|}{ Upgrades } & \multicolumn{8}{|c|}{ Downgrades } \\
\hline & \multicolumn{2}{|l|}{ (1a) } & \multicolumn{2}{|l|}{ (2a) } & \multicolumn{2}{|l|}{ (3a) } & \multicolumn{2}{|l|}{ (4a) } & \multicolumn{2}{|l|}{ (1b) } & \multicolumn{2}{|l|}{ (2b) } & \multicolumn{2}{|l|}{$(3 b)$} & \multicolumn{2}{|l|}{ (4b) } \\
\hline & Coeff & $t$-stat & Coeff & $t$-stat & Coeff & $t$-stat & Coeff & $t$-stat & Coeff & $t$-stat & Coeff & $t$-stat & Coeff & $t$-stat & Coeff & $t$-stat \\
\hline Constant & 2.4923 & 4.377 & 1.5820 & 1.805 & 1.6187 & 1.846 & 1.6447 & 1.853 & 1.3682 & 1.893 & 2.1962 & 1.813 & 2.2429 & 1.851 & 2.1791 & 1.802 \\
\hline Event & 0.1096 & 1.010 & 0.1117 & 1.034 & 0.1124 & 1.037 & 0.1115 & 1.033 & -0.2855 & -2.041 & -0.2837 & -2.027 & -0.2838 & -2.028 & -0.2829 & -2.024 \\
\hline Lag event & 0.1258 & 2.605 & 0.1284 & 2.648 & 0.1288 & 2.647 & 0.1286 & 2.651 & -0.0081 & -0.156 & -0.0083 & -0.161 & -0.0084 & -0.163 & -0.0084 & -0.162 \\
\hline $\begin{array}{c}\text { CCR (event } \\
\text { country) }\end{array}$ & -0.3834 & -8.771 & -0.3807 & -8.771 & -0.3808 & -8.798 & -0.3805 & -8.775 & 0.0018 & 0.042 & 0.0026 & 0.062 & 0.0025 & 0.060 & 0.0029 & 0.069 \\
\hline $\begin{array}{l}\text { CCR (non-event } \\
\text { country) }\end{array}$ & 0.0490 & 1.273 & 0.0549 & 1.438 & 0.0531 & 1.391 & 0.0558 & 1.457 & -0.0647 & -1.216 & -0.0650 & -1.210 & -0.0658 & -1.225 & -0.0636 & -1.184 \\
\hline Emerging & & & 1.3971 & 1.943 & 1.4406 & 2.013 & 1.4254 & 1.979 & & & -1.4537 & -1.638 & -1.4611 & -1.647 & -1.4348 & -1.617 \\
\hline Developed & & & -0.7224 & -0.975 & -0.7698 & -1.042 & -0.7379 & -0.992 & & & 1.9785 & 2.128 & 1.9742 & 2.125 & 1.9561 & 2.105 \\
\hline Adjacent & & & -0.3154 & -0.864 & -0.3213 & -0.882 & -0.3104 & -0.856 & & & 0.4443 & 1.030 & 0.4340 & 1.003 & 0.4480 & 1.036 \\
\hline Distance & & & -0.0391 & -2.514 & -0.0370 & -2.390 & -0.0384 & -2.457 & & & 0.0452 & 2.117 & 0.0456 & 2.144 & 0.0460 & 2.150 \\
\hline Language & & & 0.1001 & 0.572 & 0.1145 & 0.658 & 0.1091 & 0.623 & & & 0.2508 & 1.124 & 0.2573 & 1.158 & 0.2534 & 1.136 \\
\hline Trade bloc & & & 0.2632 & 1.022 & 0.2580 & 1.004 & 0.2579 & 1.007 & & & -0.1606 & -0.385 & -0.1684 & -0.403 & -0.1741 & -0.418 \\
\hline Common law & & & -0.2517 & -1.146 & -0.2835 & -1.288 & -0.2518 & -1.144 & & & -0.0641 & -0.185 & -0.0458 & -0.133 & -0.0603 & -0.174 \\
\hline $\begin{array}{l}\text { Portfolio } \\
\quad \text { flows - pos. }\end{array}$ & & & & & 0.0498 & 0.424 & & & & & & & -0.0018 & -0.012 & & \\
\hline $\begin{array}{l}\text { Portfolio } \\
\quad \text { flows - neg. }\end{array}$ & & & & & -0.3256 & -2.601 & & & & & & & -0.1456 & -1.054 & & \\
\hline Trade flows - pos. & & & & & & & -0.1216 & -1.013 & & & & & & & 0.0303 & 0.211 \\
\hline Trade flows - neg. & & & & & & & -0.2559 & -2.150 & & & & & & & -0.1239 & -0.899 \\
\hline Year dummies & Yes & & $\mathrm{Y}$ & & $\mathrm{Yc}$ & & $\mathrm{Y}$ & & $\mathrm{Y}$ & & Y & & $\mathrm{Y}$ & & Y & \\
\hline Event country dum. & Yes & & Y & & $\mathrm{Ys}$ & & $\mathrm{Y}$ & & $\mathrm{Y}$ & & Y & & $\mathrm{Y}$ & & $\mathrm{Y}$ & \\
\hline $\begin{array}{l}\text { Non-event country } \\
\text { dum. }\end{array}$ & Yes & & $\mathrm{Y}$ & & $\mathrm{Yc}_{\mathrm{c}}$ & & $\mathrm{Y}$ & & $\mathrm{Y}$ & & $\mathrm{Y}$ & & $\mathrm{Y}$ & & $\mathrm{Y}$ & \\
\hline Adjusted $R^{2}$ & 0.10 & & 0.1 & & 0.1 & & 0.1 & & 0.0 & & 0.0 & & 0.0 & & $0 .($ & \\
\hline $\begin{array}{l}\text { Number of } \\
\text { observations }\end{array}$ & 2862 & & 28 & & 28 & & 28 & & 28 & & 28 & & 28 & & 28 & \\
\hline
\end{tabular}

This table presents the coefficient estimates of Eq. (1) using a sample of event days. Event is the change (non-zero) in the comprehensive credit rating (CCR). Lag Event is the cumulative change in the CCR of non-event countries during the two weeks preceding the event. Matrix $X$ includes the levels of event and non-event country CCR, country status as emerging/developed, adjacency (sharing of land border), distance between countries, sharing a common official language, membership in a trade bloc, origin of legal systems, and full sets of year and country (event and non-event) dummies. Portfolio flows - pos. (neg.) is a dummy variable that takes the value one for countries with highly (lowly) correlated portfolio flows. Trade flows - pos. (neg.) is a dummy variable that takes the value one for countries with highly (lowly) correlated trade flows. Correlations are computed over a lagged rolling window of six-month. The dependent variable is the cumulative two-day $[0,1]$ non-event country stock market return spread relative to the US stock market, denominated in US dollars. All $t$-statistics ( $t$-stat) are heteroskedasticity-robust using the White correction. 
highly positively correlated portfolio or trade flows dummy does not allow us to draw conclusions regarding the increased impact in the expected direction of rating news for such country pairs. ${ }^{11}$

Second, there is evidence of incremental differential information effects only for upgrades. That is, stock market return spreads in these countries generally fall in response to an upgrade of a country with highly negatively correlated portfolio flows. Compared to the typical reaction to rating upgrades abroad, we find an incremental reduction of about 33 basis points in stock return spreads for countries with highly negatively correlated portfolio flows with the event country (or 26 basis points for trade flows). This is surprising, given the positive (although statistically insignificant) common reaction to upgrades, and suggests a possible explanation for the absence of a significant spillover for rating upgrades. $^{12}$

Overall, the investigation of differential spillover effects suggests a far more homogeneous reaction of international stock markets (non-event countries) to rating downgrades than to rating upgrades. This yields some support for the hypothesis that global equity portfolio rebalancing actions may induce differential price reactions across non-event stock markets, but only for rating upgrades.

Gande and Parsley (2005) find some evidence of a differential spillover effect in international sovereign debt markets for downgrades. Our results suggest a more homogeneous reaction of stock markets to rating downgrades abroad than the reaction observed for debt markets. Thus, the common information spillover seems to dominate the stock market reaction to bad news abroad.

\subsection{Additional tests}

Finally, we focus on the comprehensive credit rating negative change, for which we have sustained evidence of spillover effects, to address two issues. First, we look at the correlation structure among country-level portfolios. Second, we present new evidence of international information spillover effects at the industry level.

\subsubsection{Stock market correlations}

We test whether there are equal cross-country correlation matrices between event and non-event days. If the downgrade spillover effect on international stock markets is not merely a demonstration of current cross-country correlation structures, the degree of correlation across countries should change on event days. Moreover, we argue that the insignificance of differential spillover effects (for downgrades) is consistent with an increase in correlations.

\footnotetext{
11 We use dummy variables because correlations are estimated with error, and flow data are low frequency (monthly). When we run regressions (results not tabulated here) using the actual estimates of the correlation coefficients instead of the dummy variables, our primary findings remain unaffected.

12 We also run regressions using 12-month horizon portfolio or trade flow correlations (results not tabulated here). For upgrades only, the highly negatively correlated portfolio flows dummy (not the trade flows) is statistically significant, suggesting a decline in stock return spreads of about 30 basis points. This robustness suggests that the transmission channel is stronger for portfolio than for trade linkages, and that only in the short run do trade flows play a role as a transmission mechanism. We also run regressions including the four dummy variables simultaneously, and the conclusions remain virtually unchanged.
} 
To investigate these issues, we follow the Gande and Parsley (2005) research design and randomly select (with replacement) a matched (across countries) sample of non-event date return spreads for each event, imposing the additional condition that the non-event days are sampled within the window $[-60,-21]$ days relative to the event day. The sampling exercise is performed 10,000 times, and a cross-country correlation matrix is computed using each randomly selected sample of non-event day return spreads. We focus our analysis on downgrades, for which there is evidence of spillovers.

The first issue is whether correlation matrices differ between event and non-event periods. Following Kaplanis (1988) and Longin and Solnik (1995), we test this hypothesis using the Jennrich (1970) test statistic. ${ }^{13}$

The results support the conclusion that the downgrade spillover effect is not a simple manifestation of the current correlation structure, as correlations themselves change on event days relative to non-event days. The simulations yield a median test statistic of 577.96; the 5\% critical value is 453.98 (for a chi-square distribution with 406 degrees of freedom). We reject at the 5\% level the null hypothesis that correlation matrices are equal across all 10,000 simulations. Thus, our results strongly suggest that the correlation structure itself changes on event days.

The second issue is whether correlation increases (or declines) during event periods compared to non-event periods preceding the rating change. To evaluate the sign of correlation changes, we perform an element-by-element comparison between the event days' correlation matrix and each of the randomly sampled non-event day correlation matrices. Specifically, we compute the proportion of pairwise correlation coefficients that represents net increases from non-event periods to event periods. As expected, the results suggest that correlations increase on the event days. Across all 10,000 matrix evaluations, we find higher proportions of net increases than of net declines $70.6 \%$ of the time. Moreover, the $55.6 \%$ average proportion of net increases is statistically significant at the $5 \%$ level.

Our two correlation-based tests show that we can reject the hypothesis of a constant correlation structure between event and non-event periods; correlations increase during event periods.

\subsubsection{Industry portfolios}

Akhigbe et al. (1997) report that individual-firm bond rating downgrades are associated with a statistically significant negative abnormal stock return for rival firms (in the same industry). There is no evidence of industry spillover effects for bond rating upgrades, so these researchers conclude that only bond rating downgrades are informative for the firm's industry.

Our examination takes a complementary perspective. As our focus is cross-country sovereign rating change spillover effects, we ask whether a country-level event provides any information that is relevant for industries in other countries. In other words, we are looking for cross-market and cross-country spillover effects at the industry level.

We use the cumulative two-day $[0,1]$ return spread of each local industry portfolio relative to the same industry in the US as the dependent variable. TF Datastream Level 3 local industry portfolios are considered, which are based on a value-weighted aggregation

\footnotetext{
13 The Jennrich (1970) test is robust to changing volatilities from event to non-event samples (the samples whose correlations are being tested).
} 
Industry portfolios impact of sovereign rating downgrades

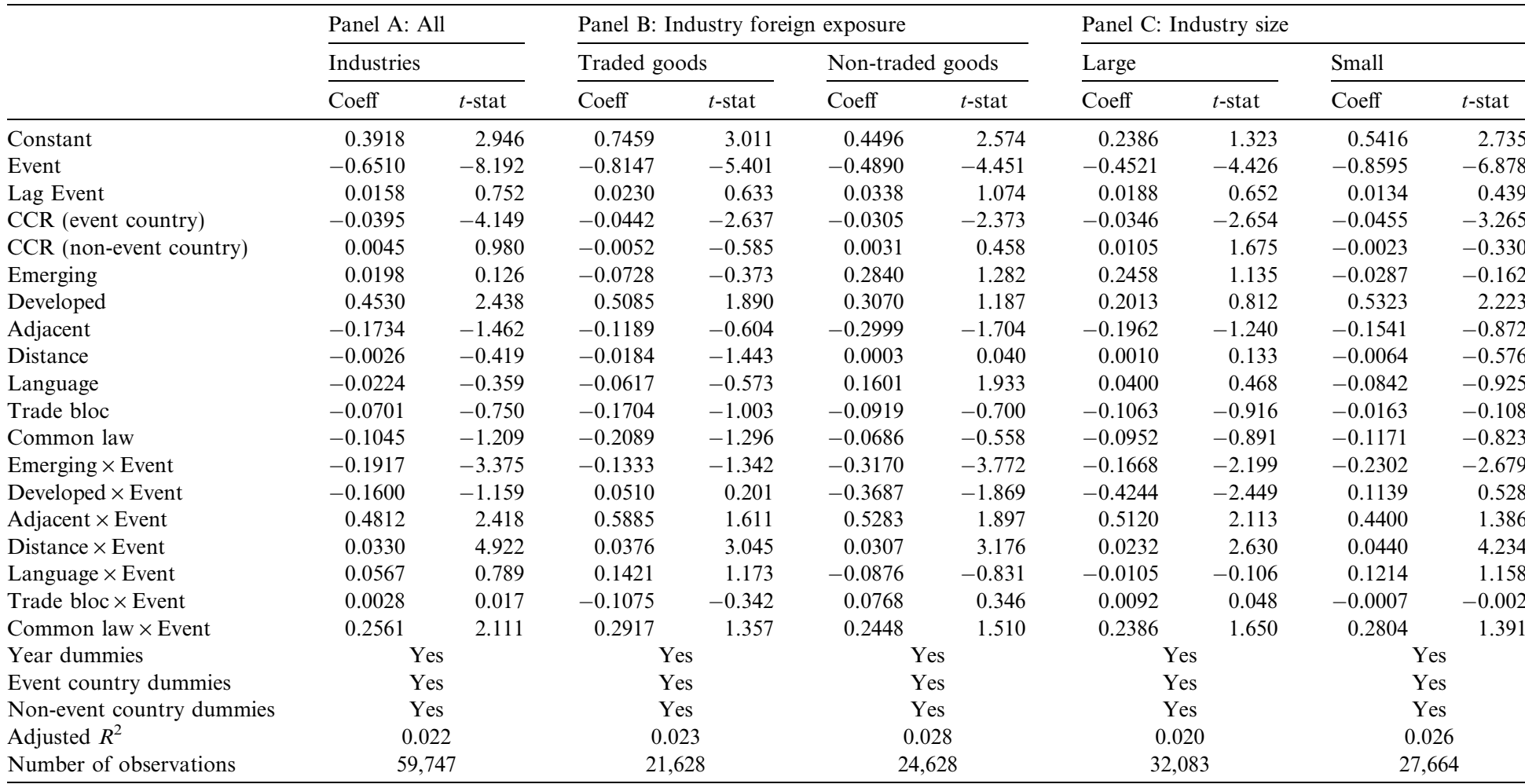

This table presents the coefficient estimates of Eq. (1) using a sample of downgrade event days and randomly selected (with replacement) non-event days at the industry level (Datastream Level 3 local industry portfolios). Event is the (negative) change in the comprehensive credit rating (CCR) on event days and zero on non-event days Lag Event is the cumulative change in the CCR of non-event countries during the two weeks preceding the event. Matrix $X$ includes the levels of event and non-event country CCR, country status as emerging/developed, adjacency (sharing of land border), distance between countries, sharing a common official language, membership in a trade bloc, origin of legal systems, and full sets of year and country (event and non-event) dummies. Panel A uses a sample of all industries. Panel B uses two samples: one of traded goods industries and the other of non-traded goods industries. Panel C uses two samples, according to their market capitalization on December 2002: one of the five largest industries and the other of the five smallest industries. The dependent variable is the cumulative two-day [0, 1] US dollar denominated return spread of each local industry portfolio relative to the same industry in the US. All $t$-statistics ( $t$-stat) are heteroskedasticity robust using the White correction. 
of stocks in a maximum of ten industries per country. We use the same set of countries as before, with the exception of Venezuela, where no data on industry portfolios are available. Next, we pool the data for all local industry portfolios excluding the event country, at each event time. As before, we add to this sample 215 randomly selected non-event day observations (at the industry level).

Table 5 presents the results. Panel A uses all industries. As in the country portfolios tests, the common (across all industries) spillover effect of sovereign rating downgrades is negative ( 65 basis points) and highly significant.

We further characterize the industry dimension of sovereign rating downgrades using subsamples of industries. First, we adopt the Griffin and Karolyi (1998) classification of industries into traded and non-traded goods, defining the latter as industries for which high transportation costs prevent international trade. There are more important variations in global industry factors for traded goods firms because profitability, cash flows, and asset values may be more sensitive to price fluctuations of internationally traded goods (inputs or outputs for the industry) and changes in the terms of competition. ${ }^{14}$

Panel B of Table 5 presents the results. We find spillover effects to be statistically significant in both traded and non-traded industries. The effect of downgrades is economically more significant for traded goods industries (about 81 basis points, negative) than for non-traded goods (49 basis points, negative). This difference probably occurs because non-traded goods industries are less sensitive to international sources of variation, such as a foreign country sovereign rating downgrade.

Second, we form two groups of five industries each, according to market capitalization in December 2002. We sum (across all countries) the market capitalization of each industry in each country and study the downgrades impact in the five largest and five smallest industries. $^{15}$

Panel C of Table 5 presents the results. We see a noticeable increase (in absolute terms) in the economic impact of sovereign rating abroad on small industries (to about 86 basis points, negative); there is a smaller impact for large industries (about 45 basis points, negative). Despite the differences across industry groups, the negative impact of downgrades is always statistically significant.

\section{Conclusion}

We ask whether a sovereign rating change (an implemented change or credit outlook/ watch move) for a given country impacts stock market returns in other countries. As with own-country stock market reaction to rating changes, the evidence reveals asymmetric spillovers. Ratings upgrades abroad have no discernible impact on stock market return spreads, but rating downgrades are associated with an economically and statistically significant negative return spread. This suggests that only downgrades abroad convey information to stock markets.

\footnotetext{
${ }^{14}$ We use a conservative approach to classify our ten industries. We consider as traded goods industries the Resources, Basic Industries, Cyclical Consumer Goods, and Information Technology industries, and as nontraded goods industries the Cyclical Services, Non-Cyclical Services, Utilities, and Financials industries. We eliminate two industries (General Industries and Non-Cyclical Consumer Goods) whose composition is mixed.

${ }^{15}$ Large industries are (in declining order): Financials, Non-Cyclical Services, Resources, Non-Cyclical Consumer Goods, and Cyclical Services.
} 
These findings are robust to control variables that proxy for possible linkages across markets, crisis periods, the nature of affected markets, the currency in which returns are measured, and to differences in the industrial structure of countries. Furthermore, we find that geographic distance is inversely related to the spillover impact. This is consistent with the hypothesis that rating news has a more pronounced effect in countries nearer to each other, where there is less information asymmetry. We also find that a country's status as an emerging market is positively associated with the downgrade impact. Rating downgrades have a greater economic impact for large-country events, small industries, and industries with considerable foreign exposure (traded goods industries).

\section{Appendix}

Table A.1

Variable definition and sources

\begin{tabular}{|c|c|c|}
\hline Variable & Description & Sources \\
\hline Emerging & $\begin{array}{l}\text { Dummy variable that equals } \\
\text { one if event and non-event } \\
\text { country are classified as } \\
\text { emerging, and zero otherwise }\end{array}$ & $\begin{array}{l}\text { Morgan Stanley Capital International } \\
\text { (http://www.msci.com) } \\
\text { Standard \& Poor's } \\
\text { (http://www.standardandpoors.com) } \\
\text { ISI Emerging Markets (http://www.securities.com) }\end{array}$ \\
\hline Developed & $\begin{array}{l}\text { Dummy variable that equals } \\
\text { one if event and non-event } \\
\text { country are not classified as } \\
\text { emerging, and zero otherwise }\end{array}$ & $\begin{array}{l}\text { Morgan Stanley Capital International } \\
\text { (http://www.msci.com) } \\
\text { Standard \& Poor's } \\
\text { (http://www.standardandpoors.com) } \\
\text { ISI Emerging Markets (http://www.securities.com) }\end{array}$ \\
\hline Adjacent & $\begin{array}{l}\text { Dummy variable that equals } \\
\text { one if event and non-event } \\
\text { country share a land border, } \\
\text { and zero otherwise }\end{array}$ & $\begin{array}{l}\text { CIA } \\
\text { (http://www.cia.gov/cia/publications/factbook/fields/2096.html) }\end{array}$ \\
\hline Distance & $\begin{array}{l}\text { The physical distance between } \\
\text { event and non-event country } \\
\text { computed as the GCD between } \\
\text { countries' capital cities }\end{array}$ & $\begin{array}{l}\text { Kristian S. Gleditsch } \\
\text { (http://weber.ucsd.edu/ kgledits) }\end{array}$ \\
\hline Language & $\begin{array}{l}\text { Dummy variable that equals } \\
\text { one if event and non-event } \\
\text { country share a common } \\
\text { language (official), and } \\
\text { zero otherwise }\end{array}$ & $\begin{array}{l}\text { CIA } \\
\text { (http://www.cia.gov/cia/publications/factbook/fields/2098.html) }\end{array}$ \\
\hline $\begin{array}{l}\text { Trade } \\
\text { bloc }\end{array}$ & $\begin{array}{l}\text { Dummy variable that equals } \\
\text { one if event and non-event } \\
\text { country share the same trade } \\
\text { bloc, Nafta, Mercosur, } \\
\text { Asean, or EU, and zero } \\
\text { otherwise }\end{array}$ & $\begin{array}{l}\text { Nafta (http://www.nafta-sec-alena.org) } \\
\text { Mercosur (http://www.mercosur.org.uy) } \\
\text { Asean (http://www.aseansec.org/home.htm) } \\
\text { EU (http://www.europa.eu.int) }\end{array}$ \\
\hline $\begin{array}{l}\text { Common } \\
\text { law }\end{array}$ & $\begin{array}{l}\text { Dummy variable that equals } \\
\text { one if event and non-event } \\
\text { country share the common law } \\
\text { legal tradition, and zero } \\
\text { otherwise }\end{array}$ & La Porta et al. (1997) \\
\hline
\end{tabular}


Table A.1 (continued)

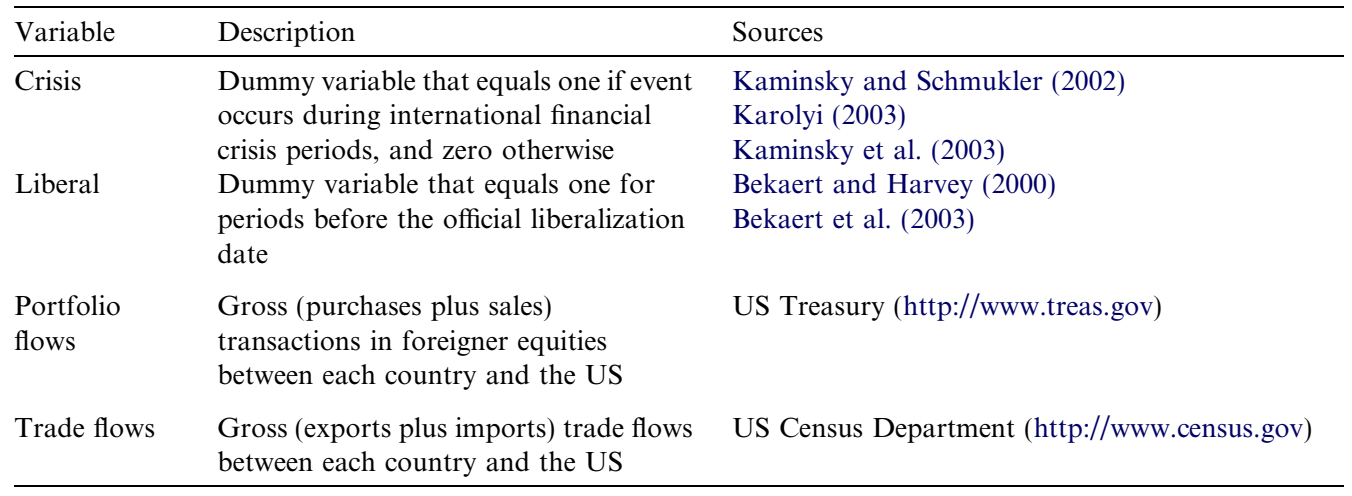

Table A.2

Comprehensive credit rating definition

\begin{tabular}{lllll}
\hline Explicit credit rating (ECR) & & & Credit outlook \\
\cline { 1 - 2 } Rating & Numerical code & & Information & Add to ECR \\
\hline AAA & 20 & & Positive & 1 \\
AA + & 19 & CW - Pos & 0.5 \\
AA & 18 & Stable/CW - Dev & 0 \\
AA- & 17 & NW - Neg & -0.5 \\
A + & 16 & & -1 \\
A & 15 & & \\
A- & 14 & & \\
BBB + & 13 & & \\
BBB & 12 & & \\
BBB- & 11 & & \\
BB + & 10 & & \\
BB & 9 & & \\
BB- & 8 & & \\
B + & 7 & & \\
B & 6 & & \\
B- & 5 & & \\
CCC + & 4 & & \\
CCC & 3 & & \\
CCC - & 1 & & \\
CC/C & 0 & & \\
SD/D & & &
\end{tabular}

\section{References}

Akhigbe, A., Madura, J., White, A., 1997. Intra-industry effects of bond rating adjustments. Journal of Financial Research 20, 545-561.

Bekaert, G., Harvey, C., 2000. Foreign speculators and emerging equity markets. Journal of Finance 55, 565-613.

Bekaert, G., Harvey, C., Lundblad, C., 2003. Equity market liberalization in emerging markets. Journal of Financial Research 26, 275-299. 
Brooks, R., Faff, R., Hillier, D., Hillier, J., 2004. The national market impact of sovereign rating changes. Journal of Banking and Finance 28, 233-250.

Campbell, J., Ammer, J., 1993. What moves the stock and bond markets? A variance decomposition for longterm asset returns. Journal of Finance 48, 3-37.

Cavaglia, S., Brightman, C., Aked, M., 2000. The increasing importance of industry factors. Financial Analysts Journal 56, 41-54.

Connolly, R., Stivers, C., Sun, L., 2005. Stock market uncertainty and the stock-bond return relation. Journal of Financial and Quantitative Analysis 40, 161-194.

Dornbusch, R., Park, Y., Claessens, S., 2000. Contagion: Understanding how it spreads. World Bank Research Observer 15, 177-197.

Gande, A., Parsley, D., 2005. News spillovers in the sovereign debt market. Journal of Financial Economics 75 , 691-734.

Goh, J., Ederington, L., 1993. Is a bond rating downgrade bad news, good news, or no news for stockholders? Journal of Finance 48, 2001-2008.

Griffin, J., Karolyi, G., 1998. Another look at the role of the industrial structure of markets for international diversification strategies. Journal of Financial Economics 50, 351-373.

Griffin, J., Stulz, R., 2001. International competition and exchange rate shocks: A cross-country industry analysis of stock returns. Review of Financial Studies 14, 215-241.

International convergence of capital measurement and capital standards - A revised framework, 2004. Bank for International Settlements, Basel Committee on Banking Supervision.

Jennrich, R., 1970. An asymptotic chi-square test for the equality of two correlation matrices. Journal of the American Statistical Association 65, 904-912.

Kaminsky, G., Reinhart, C., 2000. On crises, contagion, and confusion. Journal of International Economics 51, $145-168$.

Kaminsky, G., Schmukler, S., 2002. Emerging markets instability: Do sovereign rating affect country risk and stock returns? World Bank Economic Review 16, 171-195.

Kaminsky, G., Reinhart, C., Vegh, C., 2003. The unholy trinity of financial contagion. Journal of Economic Perspectives 17, 51-74.

Kaplanis, E., 1988. Stability and forecasting of the comovement measures of international stock market returns. Journal of International Money and Finance 7, 63-75.

Karolyi, G., 2003. Does international financial contagion really exist? International Finance 6, 179-199.

La Porta, R., Lopez-de-Silanes, F., Shleifer, A., Vishny, R., 1997. Legal determinants of external finance. Journal of Finance 52, 1131-1150.

Larrain, G., Reisen, H., von Maltzan, J., 1997. Emerging market risk and sovereign credit risk. Technical Paper No. 124, OECD.

Longin, F., Solnik, B., 1995. Is the correlation in international equity returns constant: 1960-1990? Journal of International Money and Finance 14, 3-26.

Portes, R., Rey, H., 2005. The determinants of cross-border equity flows. Journal of International Economics 65, 269-296.

Radelet, S., Sachs, J., 1998. The onset of the East Asian financial crisis. Working paper NBER.

Reisen, H., von Maltzan, J. 1999. Boom and bust and sovereign rating. Technical paper No. 148, OECD.

Rose, A., 2000. One money, one market: Estimating the effect of common currencies on trade. Economic Policy $30,9-48$.

Sovereign Credit Ratings: A Primer, 2005.

Zaima, J., McCarthy, J., 1988. The impact of bond rating changes on common stocks and bonds: Tests of the wealth redistribution hypothesis. Financial Review 23, 483-498. 